\title{
Гостра непрохідність тонкої кишки. Спірні та невирішені питання декомпресії травного каналу у світлі успіхів і невдач оперативного лікування
}

\begin{abstract}
Мета роботи: покращення безпосередніх результатів хірургічного лікування хворих на гостру непрохідність тонкої кишки (ГНТК) шляхом визначення показань до виконання різних способів декомпресії травного каналу та удосконалення відомих іï методів.

Матеріали і методи. Обстежено 221 хворого на ГНТК, які були розподілені на чотири групи: 1 - (67 (30,32 \%)) - оперовані хворі без декомпресії травного каналу; 2 - (107 (48,42 \%)) - оперовані хворі з декомпресією травного каналу; 3 - (22 (9,95 \%)) - оперовані хворі, яким виконана резекція некротизованої ділянки ТК; 4 група - (25 (11,31 \%)) - хворі, оперовані з використанням лапароскопічних технологій. Також проведено ретроспективний аналіз 30 медичних карт стаціонарного хворого померлих пацієнтів з ГНТК.

Результати досліджень та їх обговорення. При проведенні ретроспективного аналізу причин летальних наслідків операційного лікування хворих на ГНТК встановлено, що вибір неадекватного методу декомпресії травного каналу спостерігався в 28 (93,34 \%) хворих. Індекс коморбідності складав 5,5-6,07 і операційно-анестезіологічного ризику за ASA (IV-V класи) спостерігався у 24 (80,01 \%) випадках. У 67 хворих усунення непрохідності здійснювали шляхом розсічення спайок та відновлення пасажу по травному каналу. У 107 пацієнтів була виконана ліквідація ГНТК з наступною назогастроінтестинальною інтубацією. У 22 пацієнтів виконано ліквідацію непрохідності шляхом резекції ділянки ТК. Одномоментна інтраопераційна декомпресія ТК у цій підгрупі пацієнтів проведена усім хворим. У 8 (36,36 \%) осіб операцію завершено накладанням кінцевої ентеростоми-ілеостоми, у 9 пацієнтів сформовано первинний ентеро-ентероанастомоз із лапаростомою. В 5 (22,73 \%) хворих операцію завершено формуванням прямого ентеро-ентероанастомозу. Малоінвазивні втручання в об’ємі лапароскопічної адгезіотомії виконано в 25 випадках в 1-2 стадії перебігу захворювання, з компенсованим функціональним станом пацієнтів при відсутності під час операції виражених локальних змін і порушень ТК. У таких випадках декомпресія ТК не проводилася. Використання запропонованих алгоритмів застосування способів та методик декомпресії ТК дозволила прискорити відновлення моторно-евакуаторної функції травного каналу після хірургічного лікування на 2-3 доби, знизити терміни стаціонарного лікування пацієнтів в середньому на 3-4 доби.
\end{abstract}

Ключові слова: гостра непрохідність тонкої кишки; методи декомпресії.

Постановка проблеми і аналіз останніх досліджень та публікацій. Минуло 40 років, як Ю. Т. Коморовський зі співавтором (1969) [11] всвітлили в матеріалах своєї роботи спірні питання спайкової хвороби очеревини у світлі успіхів і невдач оперативного лікування. Однак до тепер питання хірургічного лікування гострої непрохідності тонкої кишки (ГНТК) залишається до кінця не вирішеним, що спонукало до вивчення ефективності різних способів декомпресії тонкої кишки (ТК) при цьому захворюванні.

Порушення функції травного каналу у таких хворих є однією з головних причин тяжкого перебігу ГНТК. Виникає синдром ентеральної недостатності, патологічна секвестрація в просвіт TK критичних об'ємів рідини та газу, що перетворює травний канал на “недренований абсцес" (Meakins J. L. та Marshall J. C., 1986) [13].

Зростання інтоксикації зумовлює розвиток синдрому поліорганної недостатності, який часто й призводить до несприятливих результатів хірургічного лікування [8]. Отже, евакуація токсичного вмісту ТК і декомпресія іï̈ при цьому захворюванні $є$ необхідною складовою в лікувальному комплексі $[6,8,14]$.
Досить ефективним способом декомпресії ТК $€$ назогастроінтестинальна інтубація (HГII) [6]. Водночас дані літератури [8] свідчать про випадки неефективного дренування ТК цим методом у післяопераційному періоді, а результати досліджень групи авторів [12] вказують, що до використання НГІІ треба ставитися “... з обережністю ... і строгих показань до її виконання немає”. Інші вказують на ефективну декомпресію травного каналу за допомогою інтубації ТК через ентеростому [3].

Отже, переваги різних методів декомпресії $€$ дискусійними і питання вибору того чи іншого способу під час операції у хворих на ГНТК остаточно ще не вирішено. В той же час ефективна декомпресія травного каналу в післяопераційному періоді у хворих на ГНТК має вирішальне значення в перебігу цього захворювання і в результатах хірургічного лікування.

Мета роботи: покращення безпосередніх результатів хірургічного лікування хворих на ГНТК шляхом визначення показів до виконання різних способів декомпресії ТK та удосконалення відомих її методів. 
Матеріали і методи. Ми обстежили 221 хворого на ГНТК непухлинної етіології. Всі хвоpi були розподілені на чотири групи: перша (67 (30,32 \%)) - оперовані хворі без декомпресії травного каналу; 2 - (107 (48,42 \%)) - оперовані хворі з декомпресією травного каналу; 3 - (22 $(9,95 \%))$ - оперовані хворі, яким виконана резекція некротизованої ділянки ТK; 4 група - (25 $(11,31 \%))$ - хворі, оперовані з використанням лапароскопічних технологій. Визначали ступінь ендогенної інтоксикації на основі динаміки величини лейкоцитарного індексу інтоксикації (ЛІІ) за Я. Я. Кальф-Калифом [10], концентрації молекул середньої маси (МСМ) [4] визначали неспецифічну резистентність організму за допомогою паличкоядерно-лімфоцитарного індексу (ПЛІ) [2]. Отримані дані порівнювалися зі строками відновлення моторно-евакуаторної функції ТК за допомогою клінічних ознак - час появи перистальтики ТК, відходження газів і появи акту дефекації. Розширена діагностична програма дозволяла нам визначити функціональний стан хворого, що має, за нашими даними і результатами інших авторів $[1,7]$, важливе значення у виборі хірургічної тактики. Крім цього, вираховували індекс коморбідності [15] і за шкалою ASA - ступінь операційноанестезіологічного ризику [16].

Крім цього, проведено ретроспективний аналіз 30 медичних карт стаціонарного хворого померлих пацієнтів на ГНТК.

Результати дослідження та їх обговорення. При проведенні ретроспективного аналізу причин летальних наслідків операційного лікування хворих на ГНТК ми встановили, що вибір не- адекватного методу декомпресії травного каналу спостерігався в 28 (93,34 \%) хворих. Наявність хронічної супутньої патології в стадії декомпенсації (індекс коморбідності 5,5-6,07) та IV-V класи операційно-анестезіологічного ризику за ASA спостерігалось у 24 (80,01 \%) випадках. НГІІ була використана у 17 (56,67 \%) хворих і в 2 (6,67 \%) - одномоментна декомпресія ТК під час операції. Порушення рухової акивності ТK після операції у пацієнтів цієї групи хворих мало першочергове значення в розвитку поліорганної недостатності - відсутність і пригнічення її спостерігалася в 96,67 \% хворих. Наростання явищ інтоксикації сприяло летальному наслідку в них.

При дослідженні хворих на ГНТК зі сприятливим перебігом захворювання було виявлено, що клінічні ознаки відновлення моторно-евакуаторної функції травного каналу після операції, які наведені в таблиці 1 , були наступними.

У пацієнтів, яким було проведено хірургічне лікування ГНТК із виконанням лапаротомії, поява перистальтики ТК в 79,59 \% випадків спостерігалося на другу-третю добу. Разом з тим, у 14,28 \% обстежених хворих поява перистальтичних звуків виявлялась на четверту-п'яту доби, що цілком було неприйнятним для пацієнтів з даним захворювання. У більш ніж половини хворих (58,16 \%) на другу-третю добу спостерігалося відходження газів, а гальмування рухової функції ТК сприяло тому, що у 40 пацієнтів (20,41 \%) дана важлива клінічна ознака була виявлена тільки на п'яту-сьому доби післяопераційного періоду. Акт дефекації у хворих на ГНТК відбувався з третьої доби після операції тільки в 9,69 \%. Натомість, у 42,35 \% випадків відновлення пасажу кишкового вмісту бу-

Таблиця 1. Час появи клінічних ознак відновлення моторно-евакуаторної фрункції травного каналу в післяопераційному періоді у хворих на ГНТК, (n=196)

\begin{tabular}{||c|c|c|c||}
\hline \multirow{2}{*}{$\begin{array}{c}\text { Післяопераційний } \\
\text { період }\end{array}$} & \multicolumn{3}{|c||}{ Клінічна ознака } \\
\cline { 1 - 4 } & поява перистальтики & відходженя газів & поява акту дефекації \\
\hline Перша доба & $12(6,12 \%)$ & - & - \\
\hline Друга доба & $99(50,51 \%)$ & $29(14,79 \%)$ & $19(9,69 \%)$ \\
\hline Третя доба & $57(29,08 \%)$ & $85(43,37 \%)$ & $39(19,90 \%)$ \\
\hline Четверта доба & $18(9,18 \%)$ & $42(21,43 \%)$ & $55(28,06 \%)$ \\
\hline П’ята доба & $10(5,10 \%)$ & $29(14,79 \%)$ & $29(14,79 \%)$ \\
\hline Шоста доба & - & $9(4,59 \%)$ & $24(12,24 \%)$ \\
\hline Сьома доба & - & $2(1,02 \%)$ & $30(15,31 \%)$ \\
\hline Після сьомої доби & - & - & \\
\hline
\end{tabular}


ло виявлено на шосту, сьому добу і навіть у більш пізньому періоді лікування, що було несприятливим прогностичним фактором перебігу ГНТК.

Гальмування моторно-евакуаторної функції травного каналу в перші три доби після операції призводило до збільшення рівня інтоксикації. В таблиці 2 наведено зміни величини ЛІІ, ПЛІ, МСМ у хворих на ГНТК в різні строки після операції.

У хворих на ГНТК до операції значення ЛІІ і ПЛІ свідчило про стабілізацію запального процесу і відновлення імунної неспецифічної відповіді організму. На першу добу після операції ЛІІ зростав більш ніж в 1,37 раза, а ПЛІ - майже у 2,5 раза, що пояснюється, на нашу думку, тяжкістю і травматичністю операційного втручання, порушенням моторно-евакуаторної і захисної функцій ШКТ і транслокацією мікроорганізмів, токсинів через порушений кишковий бар’єр. Значення ЛІІ і ПЛІ поступово на третю добу після операції зменшувалися, що вказувало на зниження активності процесів запалення в організмі і підсилення неспецифічної імунної резистентності у хворих у цей післяопераційний період. На п’яту добу після операції величина ЛІІ не поверталася до вихідних величин, однак спостерігалася нормалізація величини ПЛІ. Простежувався парадоксальний феномен - ліквідація гострої механічної непрохідності TK викликала погіршення досліджуваних показників на першу добу після операції.

На першу добу після операції у хворих на ГНТК спостерігалося суттєве підвищення рівня МСМ (на 31,50 \%) порівняно з доопераційним вмістом, що, на нашу думку, пов’язано з тяжкістю, травматичністю операційного втручання, а також з особливостями проведення загального знеболення, перебігом хвороби і т.под. На третю добу, згідно з отриманими даними, спостерігалося підвищення рівня показників інтоксикації як порівняно з другою добою післяопераційного періоду, так і з їх значеннями до операції.
Разом 3 тим, ми встановили одну парадоксальну реакцію. Зокрема, після усунення причина ГНТК, евакуації вмісту з порожнини ТК і з черевної порожнини, що потенціювали явища інтоксикації, рівень показників продовжував зростати. На нашу думку, даний факт вказує на те, що ступінь інтоксикації при ГНТК залежить не тільки від наявного її джерела, а й від функціональних і морфологічних змін в ТK, травматичності операції, медикаментозного забезпечення, яке використовувалося під час проведення наркозу. Підвищення інтоксикації пов’язано також і з порушенням моторно-евакуаторної функції шлунково-кишкового каналу, з порушенням захисного бар’єру слизової ТК, руйнуванням власних білків у печінці. На п’яту добу після операції спостерігалося суттєве зниження рівня МСМ і особливо на шостувосьму доби.

Таким чином, “критичним” періодом після операції у хворих на ГНТК була перша-третя доби, що характеризувалися підвищенням рівня інтоксикації і зниженням неспецифічної імунної резистентності організму, а відновлення моторики травного каналу призводило до зменшення рівня інтоксикації.

У першій групі (n=67) непрохідність усували шляхом розсічення спайок та відновлення пасажу по травному каналу. Як правило, це були хвоpi з першою-другою стадіями перебігу ГНТК - 63 (94,03 \%) пацієнта, з високим індексом коморбідності $(4,67-6,55)$ - 26 (38,81 \%) випадки та відсутністю інтраопераційно виявлених виражених локальних порушень ТК - 41 (61,19 \%) хворий.

Другу групу склали 107 пацієнтів, яким була виконана ліквідація ГНТК з наступною НГІІ. Показаннями до інтубації в цій підгрупі були: розширення просвіту ТК до 5 і більше сантиметрів; переповнення кишковим вмістом 2/3 і більше протяжності ТK; відсутність перистальтичних хвиль ТК. При

Таблиця 2. Показники ЛІІ, пЛІ, МСМ в обстежених хворих на ГНТК до операції і в різні терміни після хірургічного лікування, (M+m)

\begin{tabular}{||c|c|c|c|c|c|c||}
\hline \multirow{2}{*}{$\begin{array}{c}\text { Показники } \\
\text { периферійної крові }\end{array}$} & \multicolumn{6}{|c||}{ Терміни обстеження } \\
\cline { 2 - 7 } & до операції & 1 доба & 2 доба & 3 доба & 5 доба & виписування \\
\hline ЛІІ (од.) & $4,06 \pm$ & $5,56 \pm$ & $2,87 \pm$ & $2,85 \pm$ & $2,20 \pm$ & $2,26 \pm$ \\
& 0,24 & $0,58^{*}$ & $0,22^{* *}$ & $0,25^{* *}$ & $0,21^{* *}$ & $0,26^{* *}$ \\
\hline ПЛІ (од.) & $0,82 \pm$ & $2,04 \pm$ & $1,24 \pm$ & $0,77 \pm$ & $0,53 \pm$ & $0,50 \pm$ \\
& 0,07 & $0,26^{*}$ & $0,11^{*}$ & 0,07 & $0,04^{*}$ & $0,06^{*}$ \\
\hline МСМ (оптичні & $0,355 \pm$ & $0,467 \pm$ & $0,371 \pm$ & $0,408 \pm$ & $0,345 \pm$ & $0,282 \pm$ \\
одиниці) & 0,006 & $0,008^{* * *}$ & $0,004^{*}$ & $0,005^{* *}$ & $0,003^{* *}$ & $0,003^{* * *}$ \\
\hline \hline
\end{tabular}

Примітка: *-p<0,05; ** - p<0,01; *** - p<0,001 порівняно з доопераційним періодом. 
дослідженні об’єму кишкового вмісту у хворих на ГНТК, у яких був використаний НГІІ, збільшення кількості кишкового вмісту спостерігалося на третю добу післяопераційного періоду, що, на нашу думку, пов'язано з компенсацією водного балансу в організмі хворих і відновленням зовнішньої секреторної функції залоз травної системи, діяльністю печінки і підшлункової залози при недостатній евакуаторної функції ТК. Використання декомпресії ТК дозволяє зменшити всмоктування кишкових інгредієнтів та їх вплив на організм хворого.

У третю групу пацієнтів $(n=22)$, яким виконано ліквідацію непрохідності шляхом резекції ділянки ТK, увійшли хворі зі странгуляційною непрохідністю ТК - 16 (72,73 \%), тонко-тонкокишковою інвагінацією - 2 (9,09 \%), обтурацією жовчним конкрементом із некрозом стінки ТК - 3 (13,64 \%), з стороннім тілом ЧП з некрозом ділянки ТК - 1 (4,55 \%). Лікування ГНТК на фоні гострого поширеного перитоніту в цій групі проводили у 17 (72,27 \%) хворих. Одномоментна декомпресія ТK в цій підгрупі пацієнтів проведена усім 22 (100 \%) пацієнтам інтраопераційно. У 8 (36,36 \%) осіб операцію завершено накладанням кінцевої ентеростоми-ілеостоми, у 9 пацієнтів сформовано первинний ентеро-ентероанастомоз з лапаростомою, а у 5 (22,73 \%) хворих операцію завершено після одномоментної інтраопераційної декомпресії формуванням прямого ентеро-ентероанастомозу.

Малоінвазивні втручання в об’ємі лапароскопічної адгезіотомії виконано у всіх хворих 4 групи (n=25), 3 них в 1-2 стадії перебігу захворювання та 3 компенсованим функціональним станом було - 80,0 \% осіб, відсутністю під час операції виражених локальних змін і порушень ТК. У таких випадках декомпресія ТК не проводилася.

Враховуючи наш досвід в лікуванні хворих на ГНТК, ми розробили алгоритм вибору способів декомпресії TK при наявності абсолютних показань у хворих на гостру її непрохідність залежно від загального стану пацієнта та інтраопераційної ситуації (рис. 1).

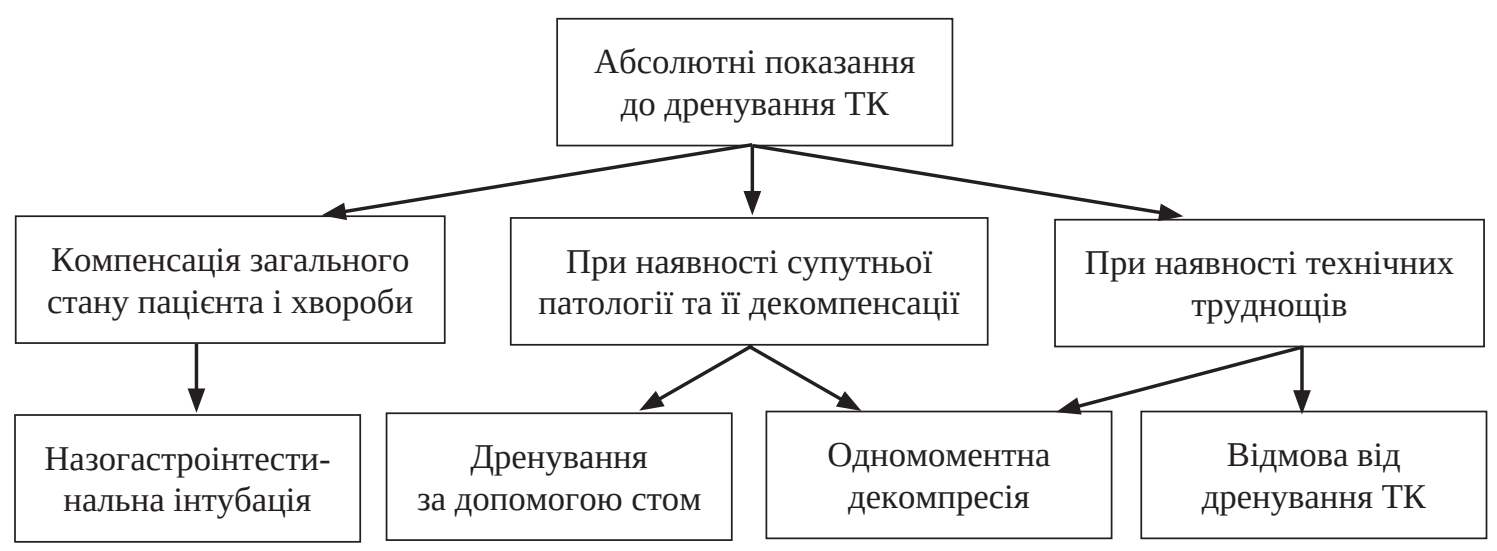

Рис. 1. Алгоритм вибору способів декомпресії тонкої кишки у хворих на гостру непрохідність тонкої кишки залежно від загального стану пацієнта та інтраопераційної ситуації.

Аналізуючи можливість застосування відкритих чи закритих методів декомпресії ТK, ми встановили, що при компенсації функціонального стану пацієнта (індекс коморбідності до 2 балів) та при наявності технічних умов (помірно виражений спайковий процес, відсутність виражених проявів порушення мікроциркуляції ТK) рекомендована назогастроінтестинальна інтубація.

При декомпенсованій супутній патології (індекс коморбідності 5 і більше балів), значній інфільтрації та виражених порушеннях кровопостачання ТK - одномоментна декомпресія або ентеростомія.

Показаннями до видалення інтубаційного зонда з ТК були поява клінічних ознак: перистальти- ка - ритмічна, задовільними хвилями, стійке відновлення пасажу по травному каналу (відсутність застійного вмісту в шлунку, самостійне відходження газів і калу), позитивні сонографічні ознаки (поява ритмічної перистальтики і відсутність підвищеної пневматизації петель ТК, зменшення діаметра петель ТК до 15 мм та товщини їі стінки до 2 мм, відсутність випоту в черевній порожнині), об’ єктивне покращення загального стану хворого і зменшення рівня інтоксикації.

Труднощі, які можуть виникати при проведені НГІІпід час операції: недостатня довжина кишкового зонда, що призводить до неповноцінної декомпресії TK і до можливого рецидиву ранньої спайко- 
вої ГНТК; спазмована кишка спричиняє труднощі при проведенні зонда і збільшує травматизацію кишки; неможливість проведення НГІІ внаслідок анатомо-фізіологічних особливостей шлунка, дванадцятипалої кишки та дуодено-єюнального переходу їх або через спайковий процес.

Використання запропонованого алгоритму застосування способів декомпресії ТК поряд з відповідною медикаментозною і хірургічною тактикою лікування хворих на гостру непрохідність тонкої кишки сприяла прискоренню відновлення моторно-евакуаторної функції травного каналу після хірургічного лікування на 2-3 доби, знизити терміни стаціонарного лікування пацієнтів в середньому на 3-4 доби.

\section{СПИСОК ЛІТЕРАТУРИ}

1. Бенедикт В. В. Особливості лікувальної тактики в післяопераційному періоді у хворих на гостру непрохідність кишки в залежності від клінічного перебігу захворювання / В. В. Бенедикт // Хірургія України. - 2005. - № 1 (13). - С. 147-151. 2. Бенедикт В. В. Про значення моніторингу стану неспецифічної резистентності організму у хворих на гостру непрохідність кишки / В. В. Бенедикт // Зб. матеріалів XVI з'їзду Всеукр. лікар. тов-ва. - Кам’янець-Подільський, 2017. - С. 216. 3. Гаин Ю. М. Синдром энтеральной недостаточности при перитоните: теоретические и практические аспекты, диагностика и лечение / Ю. М. Гаин, С. И. Леонович, С. А. Алексеев. Минск, 2000. - 265 с.

4. Габриэлян Н. И. Диагностическая ценность определения средних молекул в плазме крови при нефрологических заболеваниях / Н. И. Габриэлян, А. А. Дмитриев, Г. П. Кулаков // Клиническая медицина. - 1981. - № 10. - С. 38-42.

5. Грубник В. В. Тактичні підходи до лікування гострої кишкової непрохідності - роль і місце назоінтестинальної інкубації / В. В. Грубник, В. В. Міщенко, Ю. М. Кошель // Харківська хірургічна школа. - 2014. - № 1 (64). - С. 129-131.

6. Місце інкубації тонкої кишки в лікуванні пацієнтів з гострою злуковою кишковою непрохідністю / I. А. Даниленко, М. Г. Кононенко, Л. Г. Кащенко [та ін.] // Харківська хірургічна школа. - 2014. - № 2 (65). - С. 56-58.

7. Діагностика і тактика лікування хворих на гостру кишкову непрохідність : навч. посібн. / [Т. І. Тамм, О. Я. Бардюк, О. Б. Даценко та ін.]. - Харків, 2003. - 124 с.

8. Ерюхин И. А. Кишечная непроходимость : руководство

\section{REFERENCES}

1. Benedykt, V.V. (2005). Osoblyvosti likuvalnoi taktyky v pisliaoperatsiinomu periodi u khvorykh na hostru neprokhidnist kyshky v zalezhnosti vid klinichnoho perebihu zakhvoriuvannia [Features of therapeutic tactics in the postoperative period in patients with acute bowel obstruction depending on the clinical course of the disease]. Khirurhiia Ukrainy - Journal of Surgery, 1 (13), 147151 [in Ukrainian].

2. Benedykt, V.V. (2017). Pro znachennia monitorynhu stanu nespetsyfichnoi rezystentnosti orhanizmu u khvorykh na hostru neprokhidnist kyshky [On the importance of monitoring the state of nonspecific resistance of the body in patients with acute bowel
Висновки. 1. Інтубація тонкої кишки є одним з важливих етапів оперативного втручання у хворих на гостру її непрохідність.

2. Вибір методу декомпресії тонкої кишки у хворих на гостру непрохідність травного каналу залежить від конкретної інтраопераційної ситуації і функціонального стану пацієнта.

3. Застосування ефективних методів декомпресії травної трубки поряд з відповідним хірургічним лікуванням істотно покращує результати лікування пацієнтів на гостру непрохідність тонкої кишки.

4. Перспективними напрямками у вирішенні питань декомпресії тонкої кишки у хворих на гостру непрохідність кишки є розробка чітких стандартів до використання різних методів її дренування.

для врачей / И. А. Ерюхин, В. П. Петров, М. Д. Ханевич. СПб. : Питер, 1999. - 448 с.

9. Методические аспекты назогастроинтестинальной интубации при острой хирургической патологии / Б. С. Запорожченко, И. Е. Бородаев, О. Б. Зубков [та ін.] // Харківська хірургічна школа. - 2014. - № 2 (65). - С. 66-68.

10. Кальф-Калиф Я. Я. О гематологической дифференциации различных форм и фаз острого аппендицита / Я. Я. КальфКалиф // Хирургия. - 1947. - № 7. - С. 40-43.

11. Коморвский Ю. Т. Спорные вопросы спаечной болезни брюшины в свете успехов и неудач оперативного лечения / Ю. Т. Коморовский, И. Ю. Корчинский // Вестник хирургии. - 1969. - № 1. - С. 89-94.

12. Інтубація кишечнику: критичний погляд / М. А. Мендель, Є. В. Волостников, Ю. В. Плотніков [та ін.] // Харківська хірургічна школа. - 2014. - № 1 (64). - С. 91-97.

13. Моше Шайн Здравый смысл в неотложной абдоминальной хирургии / Пер. с англ. под ред. Б. Д. Савчука. - М. : ГЭОТАР-МЕД, 2003. - 272 с.

14. Русин В. І. Декомпресія травного каналу при спайковій кишковій непрохідності у дітей / В. І. Русин, М. І. Чаварга // Галицький лікарський вісник. - 2012. - № 3 (частина 2). - С. 104-105.

15. A new method of classifying prognostic comorbidity in longitudinal studies: development and validation / M. E. Charlson, P. Pompei, K. L. Ales, C. R. McKenzie // J. Chron. Dis. - 1987. No. 40 (5). - P. 373-383.

16. Little J. P. Consistency of ASA grading / J. P. Little // Anaesthesia. - 1995. - 50, No. 7. - P. 658-659.

obstruction]. Zbirnyk materialiv XVI zizdu Vseukrainskoho likarskoho tovarystva - Collection of Materials of XIV Congress of AllUkrainian Doctor's Society. Kamianets-Podilskyi [in Ukrainian]. 3. Gain, Yu.M., Leonovich, S.I., \& Alekseev, S.A. (2000). Sindrom enteralnoy nedostatochnosti pri peritonite: teoreticheskie i prakticheskie aspekty, diagnostika i lechenie [Enterior insufficiency syndrome in peritonitis: theoretical and practical aspects, diagnosis and treatment]. Minsk [in Russian].

4. Gabrielyan, N.I., Dmitriev, A.A., \& Kulakov, G.P. (1981). Diagnosticheskaya tsennost opredeleniya srednikh molekul $\mathrm{v}$ plazme krovi pri nefrologicheskikh zabolevaniyakh [Diagnos- 
tic value of determination of average molecules in blood plasma in nephrological diseases]. Klinicheskaya meditsina - Clinical Medicine, 10, 38-42 [in Russian].

5. Hrubnyk, V.V., Mishchenko, V.V., \& Koshel, Yu.M. (2014). Taktychni pidkhody do likuvannia hostroi kyshkovoi neprokhidnosti - rol i mistse nazointestynalnoi inkubatsii [Tactical approaches to the gastro-intestinal impairment - the role of the nasal interstitial incubation]. Kharkivska khirurhichna shkola Kharkiv Surgical School, 1 (64), 129-131 [in Ukrainian].

6. Danylenko, I.A., Kononenko, M.H., \& Kashchenko, L.H. (2014). Mistse intubatsii tonkoi kyshky v likuvanni patsiientiv z hostroiu zlukovoiu kyshkovoiu neprokhidnistiu [The place of incubation of the small intestine in the treatment of patients with acute connective bowel obstruction]. Kharkivska khirurhichna shkola - Kharkiv Surgical School, 2 (65), 56-58 [in Ukrainian]. 7. Tamm, T.I., Bardiuk, O.Ya., \& Datsenko, O.B. (2003). Diahnostyka i taktyka likuvannia khvorykh na hostru kyshkovu neprokhidnist [Diagnosis and tactics of treatment of patients with acute intestinal obstruction]. Kharkiv [in Ukrainian].

8. Eryukhin, I.A., Petrov, V.P., \& Khanevich, M.D. (1999). Kishechnaya neprokhodimost [Intestinal obstruction]. Saint-Petersburg: Piter [in Russian].

9. Zaporozhchenko, B.S., Borodaev, I.E., \& Zubkov, O.B. (2014). Metodicheskie aspekty nazogastrointestinalnoy intubatsii pri ostroy khirurgicheskoy patologii [Methodological aspects of nasogastrointestinal intubation in acute surgical pathology]. Kharkivska khirurhichna shkola - Kharkiv Surgical School, 2 (65), 66-68 [in Russian].
10. Kalf-Kalif, Ya.Ya. (1947). O gematologicheskoy differentsiatsii razlichnykh form i faz ostrogo appenditsita [On the hematological differentiation of various forms and phases of acute appendicitis]. Khirurgiya - Surgery, 7, 40-43 [in Russian].

11. Komorvskiy, Yu.T., \& Korchinskiy I.Yu. (1969). Spornye voprosy spayechnoy bolezni bryushiny v svete uspekhov i neudach operativnogo lecheniya [Controversial issues of adhesive disease of the peritoneum in the light of the successes and failures of surgical treatment]. Vestnik khirurgii - Herald of Surgery, 1, 89-94 [in Russian].

12. Mendel, M.A., Volostnykov, Ye.V., \& Plotnikov, Yu.V. (2014). Intubatsiia kyshechnyku: krytychnyi pohliad [Intubation of the intestine: a critical view]. Kharkivska khirurhichna shkola - Kharkiv Surgical School, 1 (64), 91-97 [in Ukrainian].

13. Moshe Shain. (2003). Zdravyy smysl v neotlozhnoy abdominalnoy khirurgii [Common sense in emergency abdominal surgery]. Moscow: GEOTAR-MED [in Russian].

14. Rusyn, V.I., \& Chavarha, M.I. (2012). Dekompresiia travnoho kanalu pry spaikovii kyshkovii neprokhidnosti u ditei [Decompression of the digestive canal with adhesive intestinal obstruction in children]. Halytskyi likarskyi visnyk - Galician Medical Journal, 3 (2), 104-105 [in Ukrainian].

15. Charlson, M.E., Pompei, P., Ales, K.L., \& McKenzie, C.R. (1987). A new method of classifying prognostic comorbidity in longitudinal studies: development and validation. J. Chron. Dis., 40 (5), 373-383.

16. Little, J.P. (1995). Consistency of ASA grading. Anaesthesia, 50 (7), 658-659.

Отримано 08.11.2019

Електронна адреса для листування: prodan-andrii@ukr.net

I. YA. DZIUBANOVSKYI ${ }^{1}$, V. V. BENEDYKT ${ }^{1}$, V. YA. DANCHAK ${ }^{2}$, A. M. PRODAN ${ }^{1}$

I. Horbachevsky Ternopil National Medical University ${ }^{1}$

Department of Health and Medical Supply of Ternopil City Council ${ }^{2}$

\title{
ACUTE OBSTRUCTION OF THE SMALL INTESTINE. CONTROVERSIAL AND UNRESOLVED ISSUES OF THE DIGESTIVE DECOMPRESSION IN THE LIGHT OF SUCCESSES AND FAILURES OF SURGICAL TREATMENT
}

\begin{abstract}
The aim of the work: to improve the results of surgical treatment of patients with acute obstruction of the small intestine (AOSI) by identifying indications for the implementation of various methods of decompression of the digestive canal and improving its known methods. Materials and Methods. 221 patients with AOSI were examined, who were divided into four groups: 1 - (67 (30.32 \%)) - operated patients without digestive canal decompression; 2 - (107 (48.42\%)) - operated patients with decompression of the digestive canal; 3 - (22 (9.95 \%)) - operated patients who underwent resection of necrotized tissue area; 4 - (25 (11.31 \%)) - patients operated using laparoscopic technologies. A retrospective analysis of 30 medical records of inpatient deceased patients with AOSI was also performed. Results and Discussion. Retrospective analysis showed that the choice of inadequate method of decompression of the digestive canal was in 28 (93.34 \%) patients. The comorbidity index was 5.5-6.07 and operative anesthesia risk for ASA (IV-V classes) was observed in $24(80.01 \%)$ cases. In 67 patients, obstruction was eliminated by dissecting adhesions and restoring the passage through the digestive canal. In 107 patients was performed nasogastrointestinal intubation. In 22 patients, obstruction was eliminated by resection of the SI area. Single-stage intraoperative decompression of SI in this subgroup of patients was performed in all patients. In 8 (36.36 \%) patients the operation was completed with the imposition of terminal enterostomy ileostomy, in 9 patients primary entero-enteroanastomosis with laparostomy was formed. In $5(22.73 \%)$ patients the operation was completed with the formation of direct entero-enteroanastomosis. Minimally invasive interventions in the volume of laparoscopic adhesiotomy were performed in 25 cases in 1-2 stages of the disease, with compensated functional condition of patients in the absence of pronounced local changes and disorders of SI during surgery. In such cases, SI decompression was not performed.

Using the proposed algorithms using methods and techniques of decompression of SI allowed to accelerate the recovery of motorevacuation function of the digestive canal after surgical treatment for 2-3 days, to reduce the time of inpatient treatment of patients by an average of 3-4 days.
\end{abstract}

Key words: acute small intestine obstruction; decompression methods. 


\author{
И. Я. ДЗЮБАНОВСКИЙ ${ }^{1}$, В. В. БЕНЕДИКТ
}

Тернопольский национальный медицинский университет имени И. Я. Горбачевского ${ }^{1}$

Отдел охраны здоровья и медицинского обеспечения Тернопольского городского совета ${ }^{2}$

\title{
ОСТРАЯ НЕПРОХОДИМОСТЬ ТОНКОЙ КИНКИ. СПОРНЫЕ И НЕРЕШЕННЫЕ ВОПРОССЫ ДЕКОМПРЕССИИ ПИЩЕВАРИТЕЛЬНОГО КАНАЛА В СВЕТЕ УСПЕХОВ И НЕУДАЧ ОПЕРАТИВНОГО ЛЕЧЕНИЯ
}

Цель работы: улучшение непосредственных результатов хирургического лечения больных острой непроходимостью тонкой кишки путем определения показаний к выполнению различных способов декомпрессии ЖКТ и усовершенствование известных ее методов.

Материалы и методы. Обследовано 221 больного с острой непроходимостью тонкой кишки (ОНТК), которые были разделены на четыре группы: 1 - (67 (30,32 \%)) - оперированные больные без декомпрессии пищеварительного канала; 2 - (107 (48,42 \%)) - оперированные больные с декомпрессией пищеварительного тракта; 3 - (22 (9,95 \%)) - оперированные больные, которым выполнена резекция некротизированного участка тонкой кишки; 4 группа - (25 (11,31\%)) - больные, оперированные с использованием лапароскопических технологий. Также проведен ретроспективный анализ 30 медицинских карт стационарного больного умерших пациентов с ОНТК.

Результаты исследований и их обсуждение. При проведении ретроспективного анализа причин летальных исходов операционного лечения больных с ОНТК установлено, что выбор неадекватного метода декомпрессии ЖКТ наблюдался в 28 (93,34 \%) больных. Индекс коморбидности составлял 5,5-6,07 и операционно-анестезиологического риска по ASA (IV-V классы) наблюдался у 24 (80,01 \%) случаях. У 67 больных устранения непроходимости осуществляли путем рассечения спаек и восстановления пассажа по пищеварительному каналу. В 107 пациентов была выполнена ликвидация ОНТК с последующей назогастроинтестинальной интубацией. В 22 пациентов выполнено ликвидацию непроходимости путем резекции участка ТК. Одномоментная интраоперационная декомпрессия ТК в этой подгруппе пациентов проведена всем больным. В 8 (36,36 \%) больных операция завершена наложением конечной энтеростомы-илеостомы, у 9 пациентов сформирован первичный энтеро-энтероанастомоз с лапаростомой. В 5 (22,73 \%) больных операция завершена формированием прямого энтеро-энтероанастомоза. Малоинвазивные вмешательства в объеме лапароскопической адгезиотомии выполнено в 25 случаях в 1-2 стадии течения заболевания, с компенсированным функциональным состоянием пациентов при отсутствии во время операции выраженных локальных изменений и нарушений ТК. В таких случаях декомпрессия ТK не проводилась. Использование предложенных алгоритмов применения способов и методик декомпрессии ТК позволила ускорить восстановление моторно-эвакуаторной функции ЖКТ после хирургического лечения на 2-3 сутки, снизить сроки стационарного лечения пациентов в среднем на 3-4 сутки.

Ключевые слова: острая непроходимость тонкой кишки; методы декомпрессии. 